\title{
Learning for Transformation: Empowering the Nigerian Child through Drama
}

\section{*Joseph Agofure IDOGHO}

\begin{abstract}
The search for a libertarian education; which emphasizes learnersô empowerment and transformation becomes ever imperative in this $21^{\text {st }}$ Century Nigeria society as a result of the shortcoming in learning: ñdeficient learnersò, in our education system. This deficiency in learning is undoubtedly endeared by the ñBanking concept of educationò practiced within the system as captured by Paulo Freire; has become the concern of all and sundry in our society. This paper therefore, explores the viability of drama as a potent device for learnersô empowerment and transformation: the how and why drama should be a learning tool. To achieve this, the paper investigates the validity and historical appeal of drama in education across the ages and the benefits of drama in education. It further observes a creative drama field work as its secondary data to reach its logical conclusion. The paper thus recommends that drama is a viable teaching technique and such should be employed as an alternative to the traditional teaching method; to facilitate the libertarian education needed in Nigeria educational system.
\end{abstract}

Keywords: Learning, Transformation, Libertarian education, Nigerian child, Drama

\section{Introduction}

Education holds varied but critical positions in the process of the formation and evolution of societies. Every society and culture however evolves its own pattern of education based on the aims and objectives that it is expected to achieve. Using the definitions provided by Paulo Freire in his seminal work, The Pedagogy of the

*Joseph Agofure IDOGHO of the Department of Theatre and Media Arts, Federal University Oye Ekiti, Ekiti State Email: agofurei@ gmail.com 
Oppressed, one would identify here two possible models from which education system can develop; the Banking model and the Libertarian model. For various reasons most mainstream Nigeria schools grow into what Freire identifies as the "Banking concept of education", where education acquires a "narrative character" and the teacher as an authoritative narrating subject who assumes power while the student, a passive receiving object. The process of teaching then involves passing on of information: within this model knowledge is rendered "lifeless and petrified", the student is experientially alienated from reality and understands it as a static phenomenon that can be compartmentalized and memorized. Freire however believes that education is an empowering tool to become a means to liberation for the learner.

A "Libertarian" education model on the other hand centres on learnersô empowerment: it develops the learner's ability to think critically as well as to translate those thoughts into action; thus actively contributing to the creation of his / her situation in the world. Education is an act of communication, where knowledge emerges through "invention and reinvention". Within this system the perceptive abilities of the student are strengthened and inquiry is encouraged. The individual exists with and not in the world; the self is realized through an active engagement with and transformation of the world. In this paper the researcher explores the possibility of using drama as a pedagogic tool that could and would transform and empower the learner. In other words a participatory learner, that gesture a Libertarian education - one that is dynamic and engages the learner in a sympathetic relationship with herself, other human beings and the world, one that achieves a composite intellectual, affective and imaginative growth.

Creativity and the spirit to enquire into real life problems; with the view of proffering solution challenges are intrinsic in all of us. It flows out from the wellspring of human ability to connect, to be compassionate, to question, to search and explore. Nevertheless it needs to be fostered, nurtured and allowed to flower, for it to be available to us. However, this cannot happen in a vacuum or in isolation. It can only happen when the learners are empowered in 
the teaching and learning process. However, several studies have proven that the banking system of education as mentioned earlier hinders learnerôs inquiries spirit (disempowerment)

Thus, Obadiegwu refers to this banking system of education otherwise to rote learning as problem in the mode of instruction or instructional level problem, he explains it thus:

With schooling recognized as major indicator of human development index, a lot of money and efforts have been invested in it by individuals and governments without appreciable increase in the quality of outputs. With the widening interest in education over the past decades, it is time to examine if one is moving in the right direction. The main question to ask is; does the formal school system need to be transformed for true learning to take place, for it to be in consonance with its larger environment and to enable children and educators to live and generate values considered important for human development. (199)

The underlined phrase in the above statement poses a serious problem to the Nigeria education system today. Apparently, our curricula seem to be in aberrance to the World accepted learning objectives: the acquisition of appropriate skills and attitude to perform or succeed in our modern competitive world. Thus, the need to reevaluate the current teaching and learning becomes inevitable to policies makers and all concerned.

The study reviews extant literature on the subject-matter. Thus, library and archival materials constitute the primary data of this study. While the secondary data for this study were derived from the participant observation of the creative dramatics workshop carried out with the St Michaelôs Anglican Primary School, Oye Ekiti, Ekiti by the 200 Level students of The Federal 
University Oye Ekiti in the 2014/2015 academic session; which this researcher was the course coordinator. This method was adopted because the variables of the study, which is attitudinalchange, cannot be quantified. This level of attitudinal-change could only be ascertained and explained by the direct involvement of the researchersôparticipant observation and be achieved through detail analysis and description of facts and observed phenomenon, via documentation. This corroborates Obadiegwuôs position on research methodology in Educational Theatre.

ñTo achieve the target aims, (in Educational

Theatre) the following data collection techniques have been used in the workshops: documentary observation, photographs, video recording of drama activities, performance interrogation and interviews, Ò(202).

\section{Theoretical Framework}

ñTell me, and I'll forget. Show me, and I may not remember. Involve me, and I'll understandò (An Old Native American Proverb). The above statement seems to explain the state of the Nigeria education and the need for an alternative. The current education system in Nigeria undoubtedly focuses on ñtell meò and ñshow meò: rather than ñinvolve meò, which is drama oriented.

Thus, this study hinges on Howard Gardnerô ñmultiple intelligences theoryò. Howard Gardner $\hat{\theta}$-a psychologist described his vision for schools which use multiple intelligences to incorporate authentic learning. Drama has the capacity to provide authentic learning as most of the intelligences are utilized in learning activities. For example, drama incorporates verbal linguistic learning through the use of language, scripts, vocabulary and reading. Intrapersonal learning relates to the feelings and emotions involved in drama, characterizations and how we respond as an individual, while interpersonal learning comes from working with others to create a scene or role play. Kinesthetic learning activates the physical self, the body and doing actions. As students 
re-create images, pictures, visual details, staging, movement, location and direction with drama their spatial learning skills are developed. Logical learning follows from using rational patterns, cause and effect relationships and other believable concepts involved with the drama. Sometimes music, or even the music of language, is also used in working with drama.

Drama has the unique ability to engage many different learning styles, thus facilitating connections with students and motivating most learners today. ñAs teachers, we understand that people learn differently and at different paces because of their biological and psychological differencesò (Reiff 19). ñLearning styles not only comprise the cognitive domain, but also the affective and physiological domains, ò (Oxford and Horton-Murillo 449). Even: ñone learning style is now considered to be multidimensionalò (Kinsella 26). Strong, Silver and Perini divide; verbal-linguistic intelligence into four learning preferences including mastery (knowing), interpersonal (connecting with people; social skills), understanding (discovery and reasoning) and self-expressive (creativity) (20). If learning styles are matched with appropriate teaching approaches, then student motivation, performance and achievement is more likely to increase.

A great strength of drama is in its appeal to various learning styles yet, many teachers are wary of using it for many reasons. Some of these concerns may relate to fear of losing control in the classroom, students may become too boisterous or unruly, unnecessarily loud noise levels, disturbing nearby classes and/or mass chaos. With clearly structured activities, most of these fears are unfounded. Students enjoy the activities, work together in groups and share their creative expressions. Even the timorous students are able to benefit from drama when they take on a new role and imagine themselves to be someone else.

\section{Conceptualizing Empowerment, Transformation and Drama}

Empowerment is the acquisition of power in particular domains by individuals or group including the processes of giving power to them, or processes that engenders their taking of power. What then 
does a significant learning experience theoretically represent? It is a life-event; it is a change-event; it is an event of creativity. A more sociological concept than creativity is that of empowerment. The core of the empowerment concept is a participatory approach. Nederveen Pieterse observes that: ñEmpowerment means a transformation in the individual's self-definition and his or her participation, a result of which may be changed even in the social structures of subordinationò (10). Livingstone highlights three factors which could be seen as indicators of empowerment: the expansion of a person's world-view or cultural understanding, the strengthening of one's óoiceôin discourse, and the broadening of the field of social identities or roles (54). Similarly, Obadiegwu also opines that for a learning experience to be worthwhile it must be empowering and transformative:

For learning to be viable, the present classroom method of instruction should be replaced with a more vibrant one that is inclusive of studentsôcontribution to his/her learning needs, if we are to empower them for their transformative development. The teacher-student relationship in formal school system where the teacher always assume the position of a policeman should be reversed to make way for student centred learning interaction. The nature of teacher-student relationship in modern educational learning situations has made it inevitably impossible to transform the child for today and tomorrowós needs. (201)

Learnersô empowerment and learnersô autonomy are terms that often go together. Learner autonomy refers to self-directed learning or a shift of responsibility for learning from teacher to student. Empowerment often is seen either as a prerequisite for this to occur, or as a result of the process. It seems that because the focus of most literatures in the autonomy vein has, as its focus the 
teacher-student relationship. Empowerment itself is often left unexplored (not a criticism). Here, the focus of this study is on empowerment, which implies the process of helping learners become aware that they can have an impact on their environment, and can exert some control over their circumstances. For the purpose of this article, this should be seen as distinct from learner autonomy. Empowerment as used here could result in a negotiation of classroom processes leading to learner autonomy, but there is a way to work with learners that leads towards empowerment that is independent of learners becoming self-reliant in a learning situation. Although, this study opines that the most powerful learning is autonomous, thus the focus here is on how a teacher can lead students to a more empowered state.

While, ñtransformational learning as a concept is defined as ñearning that induces more far-reaching change in the learner than other kinds of learning, especially learning experiences which shape the learner and produce a significant impact, or paradigm shift, which affects the learner's subsequent experiencesò (Clark 48). Clark thus sees Transformation learning as the process of effecting change in the frame of reference. While Dirkx in his exposition on transformative learning and transformation in the individual at four levels:

I. Transformation as Conscious-raising,

II. Transformation as Critical reflection,

III. Transformation as Development,

IV. Transformation as Individuation, (autonomous thinking).(5)

\section{Learning with Drama; the Classroom Perspectives}

The use of drama in education involves the adoption of this multifaceted system as a practical means of enabling and empowering learner. This study proposes the use of a combination of tasks and exercises that are derived from dramatic practices. These can be ends in themselves or means used to achieve further ends. The crucial and distinguishing facet of this system of drama is that, it is a performative system in that it engages the student actively in various aspects of learning. It is believed that it can be used to 
bring about a radical change in the way education is perceived and executed. Within a rigid system, drama can provide exploratory spaces and opportunities that allow the learner to use all her potentialities and develop in harmony with the world.

An advocate of longstanding in the area of drama as a valuable teaching strategy Dorothy Heathcote in Wagner, stated: ñlf you cannot increase reflective power in people, you might as well NOT teach, because reflection is the only thing in the long run that teaches anybody. Reflection is what makes the knowing something that can be touched on and assimilated for further useò (25). This illustrates Heathcoteôs absolute belief in the power of drama to increase reflection in students, teach and build on knowledge for further use.

In the last decade, constructivist learning has received increased attention and became more and more important as a learning theory. Dewey in the 1900ôs was a constructivist proponent, as Piaget who studied the developmental patterns of his own children. Vygotsky states that: ñWhat a child can do in a group today, tomorrow he can do aloneò (29). Constructivist learning involves social, active learning which creates a powerful learning environment.Constructivist learning is authentic and understanding-based; cooperative and collaborative; selfcontrolled; goal-oriented and draws on emotional intelligence. Constructivist learning helps to build confidence in students who are developing new skills. In view of this notion drama enhances all of these skills, engages multiple intelligences and also increases the power of reflection in constructing knowledge. All of these attributes contribute to the power of drama in engaging all learning styles.

\section{Validity and Historical Appeal of Drama in Education}

The power of drama to empower and transform learner is evident through its history and development. Although drama in education is more recent, other military, government and corporate business institutions have used drama as a valuable training and teaching method for many years (Taylor 53). Drama was first developed in the Prussian Army as a simulation technique for use with the recruitment of officers. The Prussians discovered that they were 
able to recruit officers who may appear qualified from paper and pencil tests but in fact, lacked strategic military decision-making skills when it came to commanding troops in the field. The solution was to introduce behavioral tests through simulation activities. Without risk to life, the potential officerôs tactical skills could be observed and thus demonstrated in a suitable manner. Officers who were able to commandeer troops successfully under the pressure of simulated battle were the ones successfully chosen as officers (Taylor 57-8).

These simulation techniques were further developed by the British Army as TEWTS, or Tactical Exercises without Troops. Command decisions were made at ótaff headquartersô without the use of troops or bullets, using the reality of analyzing intelligence reports as well as in-battle strategies and tactics (Taylor 59). The United States also began to develop training techniques for spies and agents during World War II using simulation, drama and improvisation techniques which proved to be effective. Partly as a result of this Office of Strategic Services (OSS) experience, the simulation technique was developed after the war as a tool of assessment in business management in America (Taylor 53). Apparently, a successful spy bears a close relationship to a successful manager. American Telephone and Telegraph, British Civil Service Selection Board and NASA began to use drama and simulation exercises in training and recruitment, especially to prepare astronauts for anti-gravity and space travel. Such drama and simulation teaching techniques have been further developed in sports training and are also used by motivational speakers who encourage listeners to visualize and use the power of the brain for positive reflective imaginings. Finally, last but not least, education began to develop and use drama teaching techniques with the beginning of Communicative Language Teaching; particularly during the 1970ô (Taylor 61). With communication at the center of the curriculum, classroom activities that develop this capability began to emerge.

These brief sketches of the background and development of drama through military, government, business and educational institutions demonstrates how drama, as a tool helps to successfully teach and 
train across a broad range of interests. The power of the brain to engage with authentic and understanding-based learning in a selfcontrolled, goal-oriented and active environment is apparent. Although drama is a fairly recent teaching strategy, more teachers are beginning to discover the increased capacity and benefits of drama to motivate; enable valuable learning and create more motivated engagement with learners in the classroom.

\section{Federal University Oye Ekiti's and Creative Dramatics Experience}

The Federal University Oye Ekitiô Creative Dramatics Experience was carried out with the St Michaelôs Anglican Primary School, Oye Ekiti, Ekiti State, Nigeria in the 2014/2015 academic session; with this researcher as the course coordinator. It is a programme designed for participants to use fairy tales and rhymes to explore different choices for resolving miscommunication through creative drama strategies. The facilitatorôs concept is an original participation play in which Upper Primary School pupils re-invent the ending of the Stories; uses drama techniques to teach the English Part of Speech: this is to enhance the learnerôs language development. Other procedures consist primarily of modules made up of lesson schemes and notes. Also included are song texts, exercises, games and stories that were creatively transformed into skits during the process.

Lesson notes were prepared on the basis of values that the instructor intends to inculcate. A lesson plan was written for each week of the term and lesson notes written for each lesson (the case study was based on a Nine-week lesson plan). It is crucial to state that although it is unnecessary to prepare lesson notes as for normal classroom lesson, in educational theatre, the lesson notes are not forced on the children (but, merely serves as the facilitatorôs guide).

Eventually, this idea was developed into the Build Yourself Confidence Creative Drama Programme that aim was aimed at giving a rounded and solid development to the learner in a classroom learning situation. Perhaps, the facilitator was determined to create an alternative and enjoyable way for children to build their self-confidence, explore their world personally, 
though under the guidance and supervision of a knowledgeable, facilitator.

The present researcher introduced a special project to explore the importance of the arts of the theatre in child development. As designed, the purpose was to introduce arts of the theatre into primary and secondary schools core curriculum albeit on a temporary basis, to augment the curriculum based subjects which are inadequate to cope with the learning experiences and benefits derivable from the arts. The project therefore considered new ways of appreciating / inculcating culture, appropriate societal norms, values and morals.

Specifically, Creative Dramatics is a comprehensive, enriching educational programme of the arts of the theatre, which include music, movement and acting. Appropriately so, because according to Barzun the role or purpose of Art is to enhance life: r̃From the Romantics onwards, art was supposed to deepen, enrich, distill, refine, ennoble and redeem life. These derivable influences includes: the mental and physical growth of the child towards a better adult lifeò(123).

In order to equip the participants, the student-teachers explained the task ahead. The importance of the definitions and clarification is for the purposes of participants understanding: is that these and other key words later form the thrust of the moral lessons that are contained in the lesson notes. Some of the salient words used include the following:

Creativity: variously defined as power to create through intelligence and imagination, aptitude for creating things or act of creating things in an imaginative way or the skillful and imaginative use of something to produce another.

Aesthetics: defined as the appreciation of beauty.

Intellectual Capacity: refers to the level and scope of reason, the ability to reason

Trust: the belief or willingness to believe the goodness, strength or ability of someone or something. 
Compassion: feeling of pity for the suffering of others that prompts one to help.

Authority: the power to give orders and make others obey.

Discipline: training or control using a system of punishment and aimed at producing obedience to rules

Freedom: the state of not being a prisoner or a slave

Beauty: a combination of qualities that give pleasure to the senses of the mind

Hope: a belief that something desired will happen

Truth: the quality or state of being, especially to know facts

Love: a strong feeling of deep affection for somebody or something

With these values built into the lessons, the expected outcome or objectives which the student teachers set out to achieve and were achieved include;

I. Creativity

II. Education: worthwhile learning experiences.

III. Positive interaction

IV. Confidence building

V. Concentration

VI. Discipline

VII. Values of life as in love for oneôs self etc. and

VIII. Wisdom to make reasonable choices in life 


\section{Result and Findings}

In the first lesson designed to reduce problems, on child who we shall simply refer to as (A) confesses to inability to complete his homework regularly. Upon investigation, it was found that although intelligent, he spent several hours watching television and playing until he was sleepy at bed time. This established a problem of inappropriate time management. Another child (B) who appears bigger than the others was noticed to be timid and introverted. The reason is he was made jest of, by his younger mates who constantly reminded him that he had been left behind by his peers. This made it even impossible for him to make any meaningful progress and was contemplating dropping out or perhaps worse. Case (C) was a tall bully who made life uneasy for a younger girl and another small framed boy. A few suggestive songs and public reprimand of the culprits initiated an end to those problems.

At the end of the exercise, the turn-around was very significant. Pupil (A) learnt to watch TV just for a couple of hours only as an incentive for finishing his home work; pupil (B) regained his confidence in himself and pupil (C) rather than became friends with the classmates he used to bully.

Other ways used to test whether there was significant difference among the sample was to access post interaction values and attitudes apart from direct assessment from observation are;

1. By directly interviewing the students.

2. By interviewing the teachers and school management who kept a close watch.

By interviewing the parents who were attracted to observe after being motivated by the nice report from their children and wards.

The findings show that drama, creative dramatics is more than any other else, a binding force that unites children and therefore creates and fosters a sense of belonging. That through the ability to sing and participate in its coalescent kinetic expression, music and dramatic activities provides an all round development that positively orientates the child for a better adult society. 
Conclusively, development means a progressive series of changes that occur in an orderly and predictable sequence or pattern as a result of maturation and experience. The experiences are most likely acquired through the suggestive influence of not only the parents at home but also by the teachers at school where these children spend half of their lives.

While educational theatre is designed to help children through Creative Dramatics discover and promote and manage their talents, qualities and abilities, the process involved in this discovery is the focus of this study and not the artistic quality of the end art.

The Federal University, Oye-Ekiti experiment proves that not only is creative dramatics viable tool for empowering learners, but also a feasible means of teaching/learning school subjects. It also serves as a boost to help pupils develop interest and better understanding in other subject areas such as English Language and English literature, Mathematics and Social Studies etc. The program under review was therefore planned to motivate the pupils and also attract the attention of the school management, which the project succeeded in doing.

The question of whether or not the goal of the programme was achieved is evident in the reaction of the school headmistress who appealed to the Creative Dramatics team (facilitators) to take on more classes, on a more regular basis. She also requested the student teachers to help co-ordinate their end-of-term presentation, which the study group satisfactorily executed in 2015 . The school authority assured that it will be included in their next sessionôs curriculum $i ̈$ which they did. This practice, if sustained will no doubt do our educational system a great deal of good by embarking on such projects in various locations in the country. 


\section{Conclusion and Recommendations}

Arising from the foregoing the viability of drama as a teaching is and can never be doubted. Knowledge is power and students should love to learn, especially if the learning is made excited to them. While this researcher is of the opinion that arts can be influential learning tools, drama is especially powerful if properly devised for classroom teaching and learning purpose. Drama is powerful because its inimitable balance of thought and feeling makes learning exciting, challenging relevant to real-life concerns, and enjoyable As educators, if we are not providing meaningful learning environment for children to learn, then we are not motivating them to learn.

Thus, using drama in the classroom as a means of teaching helps students learn adequately and develop academically and socially progressively. In a similar vein, the use of drama and theatre as a tool for teaching and learning has long been recognized as potent means of education and indoctrination. Although, the ways they are used today, are new, and they differ in a number of respects from the ways they have been used in the past, however, the most important point is that learning takes place when used. It is against this background that, Arts advocates and educators have recently started to explore the use of drama as an integrated way of learning in the curriculum.

Most importantly of all, using drama to teach in the elementary classroom gets students involved and gives them the power to have a key role in their education. Through drama, students became a part of the learning process rather than mere observers or inactive receptacles of the rich experience of learning; in this way, their learning was deeper, more sustained, and infinitely more complex. In other words what drama / theatre-in-education does is to transform the learner from what he/she is; empowering him/her to make changes in his/her own lives, as well as that of others and society at large which this paper has demonstrated in theory and practice. Thus, through research of the arts, drama in particular, and a close look at how people learn, one can attest that teaching using drama can enrich the classroom environment. 
This study therefore recommends that the arts, drama specifically should be employed in every classroom. It can reach students, who otherwise couldnâ be reached, and challenge students who have already grasped the concepts. Drama provides a fun means of learning. It brings the affective back into the classroom, an institute where emotions and learning are categorically divided. Recent brain research proves that emotions are linked with learning. When we connect to the concept emotionally, we will have a better understanding of it. When we teach using the arts we are linking prior experiences with new stimuli. Teaching using drama brings emotion and learning together.

\section{Works Cited}

Barzun, Jacques. The use and Abuse of Art. Princeton: Princeton University Press, 1973.

Chilver Peter, Staging a school play, New York: Harper and Row Publishers, 1967.

Clark, M. C., ñTransformational Learningò in S. B. Merriam (Ed), An Update on Adult Learning Theory, San Francisco: Jossey-Bass, 1993. (pp 47-56).

Courtney, Richard. Dramatic Curriculum. London: Heinemann Educational Books Ltd., 1980.

Dirkx, J.M. ñNurturing soul in adult learningò in Cranton P., (Ed), Transformative Learning in action, San Francisco: JosseyBass, 1997.

Freire, P., Pedagogy of the Oppressed, New York: Seabury Press, 1970.

Kinsella, K., ñDesigning group work that supports and enhances diverse classroom work stylesò.TESOL Journal, 6(1), 1996, (pp. 24-31).

Livingstone, D., (Ed.), Critical Pedagogy and Cultural Power, London: Macmillan, 1987.

Nederveen Pieterse, J., Emancipations, modern and post- modern. London: Sage, 1992.

Obadiegwu, C.C., ก̃Teaching Literature through Theatre-Making Processò in AMA: Journal of Theatre and Cultural Studies, Vol. 8, No.1, 2013, (196-202). 
Oxford, R., Hollaway, M. \& Horton-Murrillo, D., ñLanguage learning styles and strategies in the multicultural, tertiary L2 classroom. Ò System, 20, 1992, (439- 456).

Reiff, J., What Research Says to the Teacher: Learning Styles. Washington, DC: National Education Association, 1992.

Taylor, P. (Ed.), Researching drama and arts education: paradigms and possibilities. London: Falmer Press, 1996.

Verriour, Patrick. In Role: Teaching and Learning Dramatically. Ontario: Pippin Publishing Limited, 1994.

Vygotsky, L., Mind in Society: The Development of Higher Psychological Processes.Cambridge, MA: Harvard University Press, 1978.

Wagner, B. J. (ed.). Drama as a Learning Medium. Washington, DC: National Educational Association, 1976. 